\title{
HUKUM ISLAM DALAM KETATANEGARAAN \\ (TELAAH PERSPEKTIF MENJU INDONESIA BARU)
}

\author{
Oleh : Khalilullah Ahmas
}

\begin{abstract}
ABSTRAK
Sejak awal masuknya Islam di Nusantara, sejak itu pula tumbuh dan berkembang Hukum Islam ke dalam kesadaran hukum masyarakat Indonesia. Secara politik, pertumbuhan dan perkembangan itu lebih signifikan lagi dengan munculnya kerajaa-kerajaan Islam seperti Mataram, Banten, Cerebon dan lain-lain menyusul runtuhnya kerajaan Majapahittahun 1958, yang dalam hal ini para Raja mengIslamkan rakyatnya.

Namun dengan datanganya Bangsa penjajah Belanda, pemerintah Kolonial yang beragama Kristen Protestan ini melalui penasehat ahlinnya dibidang Islam, Dr. Snouck Hurgronce melakukan reduksi terhadap pemberlakuan hukum Islam bagi rakyat yang beragama Islam. Tindakanya ini yang kemudian dikenal dengan hukum adat teori reception in complexu.

Akan tetapi setelah memasuki masa kemerdekaan, mulai masa pemerintahan orde lama, orde baru dan sampai orde reformasi sekarang, hukum Islam makin mendapatkan kedudukan dan peran dalam kehidupan ketatanegaraan Indonesia. Dalam masa ketiga orde ini, peraturan perundang-undangan yang bermuatan Islam dan lembaga-lembaga Islam kian lahur dengan subur dan strategis.

Tulisan ini akan menguraikan bahwa hukum Islam mempunyai posisi yang vital dalam mengawal ketatanegaraan Indonesia, menuju Indonesia baru. Mengingat karakternya yang bersifat wahyuistik dan rasionalik dan yang memmadukan antara idealisme dean realisme hukum Islam mampu menggaransi tuntutan dinamika ketatanegaraan Indonesia.
\end{abstract}

Kata kunci: Hukum Islam, Ketatanegaraan dan Indonesia Baru. 


\section{PENDAHULUAN}

Mungkin tidak berlebihan jika dikatakan bahwa hukum Islam menurut sebagian kelompok manusia di dunia baik dari kalangan muslim iu sendiri maupun non-muslim adalah sosok yang menakutkan. Hal ini karena terjadi kekeliruan yang signifikan dalam mencerna dalam memberlakukan aturan samawi ini, sehingga terkesan hukum Islam itu kaku, kejam, menyiksa, bertentangan dengan hak asasi manusia, tidak adil, tidak manusiawi, tidak sesuai dengan tuntutan zaman dan berbagai tuduhan lai, terutama yang menyangkut hukum pidana Islam. Persepsi inilah yang menyebabkan hukum Islam mengalami kendala dan hambatan serta tidak diberlakukan secara total di bumi nusantara ini. Yang berlaku hanya terbatas dalam persoalan al-ahwal asy-syakhsiyah yang meliputi perkawinan, kewarisan dan perwakafan. Namun begitu keberadaannya tidak bisa dipungkiri sangat diperhitungkan menjadi salah satu sumber hukum nasional yang benyak memberikan konstibusi dalam mengatasi persoalan hukum di Indonesia. Hal ini dapat dibuktikan sejak zaman penjajahan Belanda sampai sekarang, hukum Islam telah mempengaruhi teori eksistensi dalam pengertian bahwa hukum Islam berada dalam hukum Nasional, sebagai bagian integral, memiliki sifat kemandirian yang diakui bekekuatan hukum nasional, keberadaannya sebagai penyaring bahan-bahan hukum nasional dan sebagai bahan utama dan unsur utama hukum nasional.

Jika dikaji secara saksama tentang perkembangan hukum Islam di Indonesia dapatlah dikatakan bahwa meskipun telah mempenagruhi kriteria dalam teori eksistensi namun kenyataannya dalam praktek mengalami fluktuasi. Pada masa penjajahan misalnya hukum Islam dapat diterima secara total yang disebut dalam teori reception in complexu, kemudian mengalami perubahan akibat pengaruh kuat dari $\mathrm{C}$. Snouck Hurgronce sebagai penasehat pemerintahan Hindia Belanda yang menghendaki hukumIslam baru bisa diakui jika tidak bertentangand engan hukum adat atau diterima oleh hukum adat. Perunbahan ini dikenal dalam teori Receptie. Dalam perkembangan selanjutnya teori Receptie dari Snouck Hurgronye itu dibalik yang semula hukum Islam harus tunduk pada hukum adat, diubah menjadi hukum adat yang harus tunduk dan baru diterima jika tidak bertentangan dengan hukum Islam. Inilah yang dikenal dengan teori Receptio a Contrario. 
Demikianlah zaman terus berputar dan hukum Islam sesuai tuntutan masyarakat muslim yang menjadi penduduk mayoritas dibumi Nusantara tidak mau ketinggalan untuk memainkan perannya dalam bidang hukum sehingga lahirlah apa yang disebut sebagai Kompilasi Hukum Islam (KHI) yang merupakan hasil ijma (konsensus) ulama dan sejumlah peraturan, keputusan dan ketetapan pemerintah yang menjadikan hukum Islam sebagai rujukan dan salah satu sumber hukum Nasional.

\section{HUKUM ISLAM}

Term hukum Islam merupakan istilah khas Indonesia yang dalam penggunaan kesehariannya mengandung ambiguitas (keracunan), yaitu sebagai padanan syariah di satu sisi dan sebagai padanan fiqh di pihak lain, kerena itu diperlukan penjelasan proporsional, agar ambiguitas ini tidak menimbulkan kesalah pahaman dalam terminologi barat, dikenal dua istilah. Pertama, Islamic Law yang menggunakan lebih berat mangacu kepada al-syariah al-islamiyah. Kedua, Islamic Jurisprudence sebagai terjemahan dari al-fiqh al-islamy. Dalam khazanah Islam, kedua istilah tersebut digunakan dalam pengertian yang berbeda. Meskipun antara keduanya terdapat hubungan erat dan tidak dapat dipisahkan. Hal ini karena al-syariah al-islamiyah dalam perjalanan sejarahnya, sebatas yang berkaitan dengan soal-soal hukum hanya dapat diaktualisasikan setelah mengalami persentuhan dengan ra'yu/rasio manusia, yang diformulasikan ke dalam term al-fiqh al-islamy. ${ }^{1}$

Dalam khazanah hukum di Indonesia istilah hukum Islam dipahami sebagai penggabungan dua kata yaitu, hukum dan Islam. Hukum menurut oxford English Dictionary adalah kumpulan aturan baik sebagai hasil pengundangan formal maupun dari kebiasaan, dimana suatu negara atau masyarkat tertentu mengaku terikat dengan anggota atau subjeknya, orang yang tunduk pada padanya atau pelakunya. Sedangkan menurut Hooker, hukum adalah setiap turan atau norma dimana perbuatan-perbuatan terpola. Dan kata Blackstone, hukum adalah suatu aturan bertindak dan diterapkan secara tidak pandang bulu kepada segala macam perbuatan baik yang bernyawa maupun tidak, rasional maupun irasional. ${ }^{2}$

\footnotetext{
${ }^{1}$ Ahmad Rofiq, Pembaharuan Hukum Islam di Indonesia, Penerbit Gema Media, Cetakan Pertama, 2001 Yogyakarta. h. 13.

${ }^{2}$ Ibid., h. 21
} 
Islam secara harfiah berarti menyerahkan diri atau selamat atau juga kesejahteraan. Maksudnya, orang yang mengikuti Islam, ia akan memperoleh keselamatan dunia dan akherat. Menurut Mahmud Syaltud, Islam adalah agama Allah yang dasar-dasar dan syariatnya diturunkan kepada Muhammad saw dan dibebankan kepada umat manusia. Apabila kedua kata hukum digabungkan menjadi hukum Islam, maka dapat dipahami sebagai hukum yang siturunkan Allah melalui RasulNya, unntuk disebarluaskan dan dipedomani umat manusia guna mancapai tujuan hidupnya selamat di dunia dan sejahtera di akhirat. ${ }^{3}$

Selanjutnnya istilah hukum Islam menurut Prof. Hasby ash-Shiddieqy seperti dikutip Amir Syarifuddin adalah koleksi daya upaya para ahli hukum untuk menerapkan syariat atau kebutuhan masyarakat. Jadi hukum Islam adalah peraturanperaturan yang dirumuskan berdasar wahyu Allah dan sunnah RasulNya tentang tindak laku mukhallaf yang diakui dan diyakini berlaku mengikat bagi semua pemeluk Islam. Dengan demikian, kedudukan hukum Islam sangat penting dan menentukan pandangan hidup secara tingkah laku mereka. Di sinilah, kata hukum Islam merupakan formulasi dari syariah dan fiqh sekaligus. Artinya meskipun hukum Islam merupakan aktifitas nalar, ia tidak bisa dipisahkan eksistensinya dari syariah sebagai panduan dan pedoman yang datang dari Allah sebagai al-Syari'. ${ }^{4}$

\section{Karakteristik Hukum Islam}

Dalam bukunya Conflict and Tensions in The Islamic Jurisprudence Coulson mengidentifikasi karakteristik hukum Islam sebagai berikut: ${ }^{5}$
a. Wahyu dan Akal
b. Keseragaman dan Keberagaman
c. Otoritarianisme dan Liberalisme
d. Idealisme dan Realisme
e. Hukum dan Moralitas Stabilitas dan Perubahan

\footnotetext{
${ }^{3}$ Ibid., h. 22

${ }^{4}$ Ibid., h. 23

${ }^{5}$ Ibid., h. 25
} 


\section{Ciri-Ciri Hukum Islam}

Dr. Ahmad Rofiq, MA. Menurunkan empat ciri khusus hukum Islam:

a. Hukum Islam merupakan aturan-aturan yang ditarik atau yang merupakan hasil pemahaman dan dedukasi dari ketentuan-ketentuan yang diwahyukan Tuhan kepada nabi Muhammad saw.

b. Hukum Islam itu bersifat keagamaan, berlandaskan pada keimanan dan akhlak mulia.

c. Hukum Islam tidak selamanya bersifat memaksa sebagiannya bersifat korektif dan persuasif.

d. Ruang lingkup hukum Islam meliputi seluruh jenis perbutan, baik dalam berhubungan dengan Tuhan maupun dengan diri dan sesamanya (ibadah dan muamalah).

\section{Ragam Produk Pemikiran Hukum Islam}

Menurut Dr. Ahmad Rofiq, $\mathrm{MA}^{6}$ ada empat ragam produk pemikiran Hukum Islam. Pertama, Fiqh yang telah ditemukan di atas. Kedua, keputusan pengadilan. Dalam istilah teknis disbut dengan al-qada' atau al-hukm yaitu ucapan (dan atau tulisan) penetapan atau keputusan yang dikeluarkan oleh badan yang diberi kewenangan untuk itu (Wilayah al-qada'). Ketiga, Fatwa, yaitu hasil ijtihad seorang mufti atau kelembagaan sehubungan dengan peristiwa hukum yang diajukan kepadanya. Jadi fatwa lebih khusus dari pada fiqh atau ijtihad secara umum. Keempat, perundang-undangan yaitu aturan yang dibuat oleh suatu badan legislatif (al-sultah altasyri”'iyah) yang mengikat setiap warga dimana undang-undang itu diberlakukan yang apabila dilanggar akan mendatangkan sanksi.

\section{Hukum Islam Dalam Ketatanegaraan}

Hukum Islam di Indonesia telah lama hidup dalam kesadaran hukum masyarakat Islam di Indonesia, seiring dengan pertumbuhan dan perkembangan agama Islam. Ini dapat ditelusuri pada masa-masa awal masuk Indonesia. Oleh karena itu Islam telah diterima oleh bangsa Indonesia jauh sebelum penjajah datang ke Indonesia. Waktu penjajah Belanda datang di Indonesia (Hindia Belanda) merka

\footnotetext{
${ }^{6}$ Ibid., h. 30
} 
menyaksikan kenyataan bahwa di Hindia Belanda sudah ada hukum yang berlaku, yaitu agama yang dianut oleh penduduk Hindia Belanda, seperti Islam, Hindu, Budha dan Nasrani, disamping hukum adat bangsa Indonesia (adatretch). Berlaku Hukum Islam bagi sebagain besar penduduk Hindia Belanda berkaitan dengan munculnya kerajaan-kerajaan Islam setelah runtuhnya kerajaan Majapahit pada sekitar tahun1518 M. Menurut C. Snouck Hurgronje sendiri bahwa pada abad ke 16 di Hindia Belanda sudah muncul kerajaan-kerajaan Islam, seperti di Mataram, Banten dan Cirebon yang berangsur-angsur mengislamkan penduduknya. ${ }^{7}$

Walaupun pada mulanya kedatangan Belanda (yang beragama Kristen Protestan) ke Hindia Belanda tidak ada kaitannya dengan masalah hukum agama, namun pada perkembangan selanjutnya, akhitnya mereka bisa menghindar terjadinya persentuhan dengan masalah hukum yang berlaku bagi penduduk pribumi (inlander). Sehunbungan dengan berlakunya hukum adat bagi bangsa Indonesia dan hukum agama bagi masing-masing pemeluknya, mencullah beberapa teori yang dikenal dengan teori Receptio in Complexu, teori Receptie (Resepsi), teori Reseptie Exit dan Teori Receptio A Contrario serta teori Eksistensi. Dua teori pertama muncul pada masa sebelum Indonesia merdeka dan tiga teori terakhir muncul setelah Indonesia merdeka.

Menurut Ismail Sunny, kedudukan hukum Islam pada masa penjajahan Belanda dibagi kepada dua periode yaitu: (1). Periode penerimaan Hukum Islam sepenuhnya, dan (2). Periode penerimaan Hukum Islam oleh hukum adat.

Periode penerimaan hukum Islam sepenuhnya berlangsung pada masa dianutnya teori Receptio in Complexu dengan memberlakukan hukum Islam secara penuh terhadap orang Islam, karena mereka telah memeluk agama Islam. Sedangkan periode penerimaan hukum Islam oleh hukum adat berlangsung pada masa dianutnya teori Receptio yang memberlakukan hukum Islam terhadap orang Islam, apabila hukum Islam itu telah dikehendaki dan diterima oleh dan menjadi hukum adat mereka.

Selanjutnya menurut Ismail Sunny, setelah Indonesia mereka kedudukan hukum Islam dalam ketatanegaraan Indonesia dibagi kepada periode, yaitu (1).

\footnotetext{
${ }^{7}$ Ibid., h.55
} 
Periode penerimaan hukum Islam sebagai sumber persuasif (Persuasive Source), dan (2). Periode penerimaan hukum Islam sebagai sumber otoritatif (Authoritative Source).

Hukum yang dibuat di negara Republik Indonesia yang berdasarkan Pancasila, harus memperhatikan rasa keadilanmasyarakat Indonesia, terutama umat Islam yang jumlahnya mayoritas. Apabila hukum yang dibuat tidak memprehatikan rasa keadilan hukum yang dianut oleh masyarakat, maka hukum itu akan ditolak oleh masyarakat tempat hukum itu diberlakukan. Berkaitan dengan berlakunya hukum dalam masyarakat Teuku Muhammad Radhi (mantan Kepala BPHN) mengemukakan antara lain sebagai berikut:

"Salah satu syarat bagi dapat berlakunya hukum dengan baik dalam masyarakat ialah bahwa hukum tersebut haruslah sesuai dengan aspirasi dan kebutuhan masyarakat. Adalah suatu hal yang tidak dapa dipungkiri pula bahwa masyarakat Indonesia sebagian terbesar beragama Islam dan karenagnya dapat dipahami apabila keinginan agar dalam penyusunan hukum nasional pihak berwenang mengindahkan Hukum Islam dan jangan hendaknya dalam hukum nasional yang akan datang terdapat hal-hal yang bertentangan dengan hukum Islam tersebut."

Berlakunya hukum Islam sebagai hukum positif bagi umat Islam Indonesia yang merupakan jumlah mayoritas di negeri ini, dilandasi oleh nilai-nilai filosifis, yuridis dan sosiologis beangsa Indonesia. Oleh karena itu negara berkewajiban untuk menjadikan hukum Islam sebagai hukum positif bagi umat Islam Indonesia. Karena pada dasarnya cara berpikir, pandangan hidup dan karakter suatu bangsa tercermin dalam kebudayaan dan hukumnya.

Dalam negara Indonesia yang berdasar Pancasila dan mayoritas penduduknya beragama Islam, membawa kosekuensi bahwa hukum yang berlaku di Indonesia harus tetap konsisten dengan dilandasi oleh nilai-nilai ke-Tuhanan Yang Maha Esa (sebagai sila pertama Pancasila yang menyinari sila-sila lainnya) dan tetap mengindahkan nilai-nilai hukum agama Islam. Sebaliknya hukum di Indonesia, khususnya yang berlaku bagi umat Islam Indonesia, tidak boleh mengandung ketentuan yang bertentangan dengan hukum Islam, dengan demikian di dalam negara hukum Pancasila yang penting adalah hukum nasional yang sumber utamanya adalah hukum Islam selain Pancasila. 
Umat Islam Indonesia telah menerima Pancasila sebagai dasar Negara, karena rumusan sila-sila Pancasila tersebut tidak bertentangan dan terdapat kesesuaian dengan ajaran Islam. Apalagi kalau melihat rumusan Pancasila yang terdapat dalam Piagam Jakarta yang telah diberlakukan kembali oleh dekrit Presiden tanggal 5 Juli 1959. Pada saat ini melalui jalur syiyasah hukum Islam dalam bidang-bidang tertentu telah terakomodasi dalam prundang-undangan dengan demikian ia telah menjadi bagian dari hukum positif di Indonesia yang berdasarkan Pancasila.

Selanjutnya sebagai dasar UUD 1945 dilihat naskah dan isinya adalah Islami. Demikian juga dengan pelaksanaan UUD 1945 tersebut sudah banyak yang Islami, baik itu yang menyangkut institusi keagamaan seperti terbentuknya Departemen Agama, Peradilan Agama, Majelis Ulama Indonesia, Perguruan Tinggi Agama (seperti AIAN/STAIN), maupun perundang-undangannya, seperti Undang-Undang No. 7 tahun 1989, Undang-Undang No. 17 tahun 1999, Undang-Undang No. 38 tahun 1999 dan PP Bo. 281977 mengenai segi pelaksanaan UUD 1945 ini kaitan dengan kedudukan agama didalamnya, Ahmad Sukardja menulis:

"Sekalipun dalam segi pelaksanaan UUD 1945 masih ada kekurangan, namun kedudukan agama dan terhormat, serta suasana keagamaan di Indonesia cukup baik dan semarak. Ibadah Mahdhah dapat dilaksanakan oleh setiap orang tanpa rintangan dari Pemerintah, bahkan sebaliknya Pemerintah memberikan jaminan dan dorongan. Pelaksanaan hkum keluarga (Perkawinan dan Kewarisan) menurut agama sebagai aspek hukum yang fundamental dalam keluarga muslim, sudah dijamin dengan ditetapkannya Undang-Undang Perkawinan, Kompilasi Hukum Islam dan Peradilan Agama. Pendidikan agama telah dimantapkan dalam Undang-Undang Sistem Pendidikan Nasional.

\section{Telaah Perspektif Menuju Indonesia Baru}

Kondisi bangsa Indonesia yang dipimpin rezim Orde Baru selama lebih dari 30 tahun pada akhirnya mengalami titik jenuh, mencapai anti klimaks, kemudian Orde Reformasi tampil di Panggung sejarah Republik Indonesia berkumandang lantang menyerukan berbagai perombakan, perubahan dan pembaharuan dalam berbagai aspek kehidupan. Meskipun kenyataan gerakan ini belum efektif. Gerakan Indonesia Baru pada hakikatnya adalah gerakan yang bercita-cita membentuk masyarakat madani/Civil sociaty yang menuntut terjadinya reformasi total dalam semua bidang 
kehidupan termasuk bidang hukum. Oleh karena itu, telaah perspektif menju Indonesia baru paling tidak mengacu pada adanya gerakan pembaharuab/tajdid dengan mencurahkan sumber daya pemikiran, intelektualitas dan melakukan ijtihad, merumuskan formulasi baru dalam hukum Islam. Lebih-lebih jika dikaji kondisi hukum Islam dalam hal ini figh atau Islam yurisprudence tampaknya perlu dikondidkan dengan tuntutan zaman dan masyarakat yang terus berkembang akibat terjadinya akulturasi dan penetrasi kebudayaan asing.

Menurut Azyumardi Azra, pembaharuan bertitik tolak dari asumsi atau pandangan bahwa Islam sebagai realitas dan lingkunagn sosial tertentu tidak sebsuai atau bahkan menyimpang dari apa yang dipandang sebagai Islam yang sebenarnya. Islam yang lebih sesuai dengan Islam ideal, sesuai dengan cara pandang, pendekatan dan latar belakang sosio kultural dan keagamaan individu dan kelompok pembahara yang bersangkutan. (h. 97 Pembaharuan Hukum Islam di Indonesia).

Prof. Harun nasution menegaskan bahwa pembaharuan diperlukan untuk menyesuikan paham-paham keagamaan Islam dengan perkembangan baru yang ditimbulkan akibat kemajuan ilmu pengetahuan dan teknologi modern. Sikap Harun Nasution ini dibenarkan oleh Ahmad Rofiq dengan alasan karena perkembangan sains dan teknologi dalam kenyataan membawa perubahan nilai, sistem dan sekligus problema terutama dalam bidang hukum yang sudah tentu memerlukan jawaban dan penyelesaian. Dengan jalan pembaharuan inilah pemimpin-pemimpin Islam modern mengharap akan dapat melepaskan umat Islam dari suasana kemunduran untuk selanjutnya dibawa kepada kemajuan. (h. 98)

Hukum Islam sebagi penata sosial memiliki dua fungsi, pertama sebagai kontrol sosial dan kedua sebagai nilai baru dan proses perubahan sosial. Jika yang pertama hukum Islam ditempatkan sebagai blue print atau cetak biru Tuhan yang selainsebagai kontrol juga sekaligus sebagai social enginering terhadap keberadaan suatu komunitas masyarakat. Sementara kedua, hkum lebih merupakan produk sejarah yang dalam batas-batas tertentu diletakan sebagai justifikasi terhadap tuntutan perubahan sosial, budaya dan politik. Oleh itu dalam konteks ini, hkum Islam dianut akomodatif terhadap persoalan umat tanpa kehilangan prinsip-prinsip dasarnya. Sebab kalau tidak, besarkemungkinan hukum Islam akan mengalami kemandulan fungsi atau meminjam istilah Abdurahman Wahid, fosilasi bagi kepentingan umat. Karena itu, 
apabila para pemikir hukum tidak memiliki kesanggupan atau keberanian untuk memformulasi dan mengantisipasi setiap persoalan yang timbul dalam masyarakat dan mencari penyelesaian hukumnya, maka Hukum Islam akan kehilangan aktualitasnya.

Semua ahli hukum Islam dari seluruh generasi, sekalipun generasi klasik, mengakui eksistensi pembaharuan hukum dalam Islam sebagai konsekuensi keyakinan atau Islam sebagai ajaran universal. Mereka bersepakat bahwa pembeahruan tidak dapat diberlakukan pada aspek-aspek religius, yakni aspek ubudiyyah dan nilai-nilai moral Islam. Perbedaan yang muncul adalah pembaharuan hukum pada aspek-aspek sosial ( ghoru Ubudiyyah). (h. 167 Met. Pemnh Huk Islam)

Hukum Islam dalam persepektif menuju Indonesia baru harus ditandai dengan gerakan ijtihad Fazlur Rahman membengun konsep ijtihad yang khas dan selanjutnya merupuskan metodiknya yang khas pula. Menurut Rahman, ijtihad merupakan suatu usaha yang keseluruhan unsur-unsurnya mengandung muatan jihad (perjuangan) intelektual. Ia mendefinisikan ijtihad dalam sebuah konsep yang sekaligus mengandung implikasi metodologis, metodis dan fungsional, sebagai barikut:

Ijtihad means the effort to understand the meaning of a relevant text or precedent in the past, containing a rule and to alter that rule by ectending or restricting or otherwise modifying it in such a manner tha a new situasions can be subsumed under by anew sulusion." (Ijtihad berarti upaya memahami makna suatu teks atau preseden di masa lampau dengan mengandung suatu aturan dan mengubah aturan tersebut dengan cara memperluas atau membatasi ataupunmomodifikasi dengan cara-cara yang lain sedemikian rupa sehingga suatu situasi baru dapat dicakup kedalamnya dengan suatu solusi baru). H. 148 F. Rahman.

Item-item hukum Islam yang perlu ditelaah dalam perspektif menuju Indonesia Baru adalah:

- Persamaan kedudukan manusia

- Hukum perkawinan

- Poligami

- Hak istri untuk bercerai

- Kesaksian wanita 
- Hukum waris

- Kedudukan cucu yatim sebagai ahliwaris pengganti

- Pembagian warisan dengan cara damai

- Bunga bank dan riba

- Antara zakat dan pajak

- Keluarga berencana

- Hukum potong tangan

- Hukum perkawinan

\section{Kesimpulan}

Disimpulkan hal-hal sebagai berikut:

1. Dalam sistem ketatanegaraan, hukum Islam mendapat perhatian dan diperhitungkan, sehingga ia menjadi bagian integral, menjadi salah satu sumber dan filter bagi hukum nasional.

2. Hukum Islam dalam pengertian syariah bersifat absolut karena datang dari Allah swt, tidak bisa dirubah, sedangkan hukum Islam dalam pengertian fiqh adalah bersifat relatif, karena hasil rekayasa pemikiran dan ijtidah manusia. Oleh karena itu bisa mengalami perubahn dan pembaharuan.

3. Untuk menuju Indonesia Baru, yang bercita-cita membentuk masyarakat madani/civil sociaty, pembaharuan dan ijtihad untuk memformulasikan hal-hal yang baru sesuai dengan kebutuhan dan tuntutan zaman.

4. Hukum perkawinan, perwakafan dan kewarisan sebagai al-Ahwal alAsyksiyyah perlu diamandemen agar keberadaanya ini dirasakan adil dan manusiawi sehingga konsekuensi logis dari siniHukumIslam selalu aktual dan rasional. 